Tropical Journal of Pharmaceutical Research June 2015; 14 (6): 967-976

ISSN: $1596-5996$ (print); 1596-9827 (electronic)

(C) Pharmacotherapy Group, Faculty of Pharmacy, University of Benin, Benin City, 300001 Nigeria.

All rights reserved.

Available online at http://www.tjpr.org

Original Research Article

http://dx.doi.org/10.4314/tjpr.v14i6.5

\title{
C5 Extract Induces Apoptosis in B16F10 Murine Melanoma Cells through Extrinsic and Intrinsic Apoptotic Pathways and Sub-G1 Phase Arrest
}

\author{
Baatartsogt Oyungerel ${ }^{1}$, Seungyun Chung ${ }^{1}$, Do-Young Yoon ${ }^{2}$, Tae-Young Han ${ }^{3}$, \\ Il-Young Han ${ }^{4}$, Kee-Tae Kweon ${ }^{5}$, Kyeng-Min Kim ${ }^{6}$, Gwang-Joo Jeon ${ }^{6}$ and Kang- \\ Duk Choi ${ }^{6 *}$ \\ ${ }^{1}$ School of Oriental Medicine, Dongguk University, Siksa dong, Ilsan, ${ }^{2}$ Department of Bioscience and Biotechnology, \\ Bio/Molecular Informatics Center, Konkuk University, ${ }^{3}$ BanryongInsu Herb Clinic, Nonhyun-dong, Kangnam-ku, Seoul, ${ }^{4}$ Sunwun \\ Biophysic, Ansung, Kyungki-do, ${ }^{5}$ Department of Oriental Medical Food \& Nutrition, Semyung University, Jecheon, Chungbuk, \\ ${ }^{6}$ Genomic Informatics Center, Hankyong National University, Anseong, Gyeonggi-do, Republic of Korea
}

*For correspondence: Email: kchoi04@hknu.ac.kr; Tel: +82-316705422; Fax: +82-316705339

Received: 25 December 2014

Revised accepted: 10 May 2015

\begin{abstract}
Purpose: To investigate the anti-cancer activities of C5 extract (C5E), a new herbal preparation from Korea, on B16F10 cells.

Methods: The anti-proliferative effects of C5E were assessed by culturing B16F10 cells in the presence or absence of C5E. Cell cycle progression was analyzed by PI staining using flow cytometry. The quantities of apoptosis-inducing proteins were measured by Western blot.

Results: C5E inhibited the proliferation of B16F10 cells but not human keratinocytes. C5E induced S phase arrest by interfering with cell regulatory factors such as cyclins B1, D1, D3, and E, and cyclindependent kinase 2, in B16F10 cells. Furthermore, immunoblot analysis confirmed that treatment with C5E induced apoptosis and cleaved caspase-3, poly (ADP-ribose) polymerase, via extrinsic pathway, whereas Bcl-2 expression was down-regulated. In addition, the suppression of cell proliferation by C5E is through down-regulation of $p$-Akt, up-regulation of phosphatase and tensin homolog protein expression via phosphoinositol 3 kinase survival signaling pathways in B16F10 cells. The combined cytotoxic effects of C5E and vinblastine generated $10 \%$ increase in activity in contrast to the sum of the inhibitory effects of the individual agents.

Conclusion: C5E shows promising anti-cancer activity and can be a useful adjuvant with vinblastine in combination therapeutic treatment of skin cancer.
\end{abstract}

Keywords: Melanoma, Apoptosis, Anti-cancer, p53, Vinblastine, Cell cycle arrest, Caspase

Tropical Journal of Pharmaceutical Research is indexed by Science Citation Index (SciSearch), Scopus, International Pharmaceutical Abstract, Chemical Abstracts, Embase, Index Copernicus, EBSCO, African Index Medicus, JournalSeek, Journal Citation Reports/Science Edition, Directory of Open Access Journals (DOAJ), African Journal Online, Bioline International, Open-J-Gate and Pharmacy Abstracts

\section{INTRODUCTION}

Metastasis, invasion, angiogenesis, and uncontrolled growth are characteristics of cancer. Cancer is a fatal disease that requires a multipronged therapeutic approach. Chinese herbal medicines exert multiple effects to inhibit metastasis, angiogenesis, and tumor growth [1].
Herbal medicines are generally abundant with low cost, and relatively non-toxic, and plant extracts are thought to be therapeutically superior to anti-cancer drugs in some cases $[2,3]$. Apoptosis is an important mode of programmed cell death, which is very different from necrosis [4]. Apoptotic cells undergo characteristic changes such as chromatin 
condensation, nuclear fragmentation, and blebbing [5].

To prevent tumorigenesis, it is very important to eliminate abnormal cells by apoptosis at early stage. Apoptosis is regulated by either the extrinsic or the intrinsic apoptotic pathway $[6,7]$. The extrinsic pathway involves caspase-8 activation leading to the activation of downstream effectors caspases- 3 and poly (ADP-ribose) polymerase (PARP) [8]. On the other hand, the intrinsic pathway depends on stress signals from within the cells, leading to the activation of caspase-9 through the release of mitochondrial factors, and then causing the activation of caspase-3 and PARP $[9,10]$. However, cancer cells, especially metastatic cancer cells, are commonly resistant to both apoptotic pathways. Thus, agents that can induce apoptosis in cancer cells would be effective for cancer treatment [11]. The phosphoinositol 3 kinase (PI3K)/Akt/ mammalian target of rapamycin (mTOR) pathways are important signaling pathways regulating cell growth, survival, and motility in cancer cells [12]. PI3K is mutated in many cancers and these mutations cause the kinase to be more active $[13,14]$. Akt is involved in the nuclear factor kappa B (NF-kB) signaling pathway mediated through inhibitor of kappa $B$ (IkB) kinase (IKK) regulation. [15]. mTOR has been identified as a downstream target of both the PI3K $[16,17]$ and Ras [18,19] signaling pathways. Chemotherapy is one of the primary therapeutic approaches used to treat cancer patients. However, in many cases, chemotherapy alone cannot achieve satisfactory effects, and it causes severe side effects at effective doses.

Vinblastine is an anti-microtubule drug used to treat certain kinds of cancer. Vinblastine was first used in 1958 to treat Hodgkin's Iymphoma; vincristine was introduced in 1962 [20]. Vinblastine is one of the most effective cytotoxic agents for the treatment of a variety of solid malignant tumors such as melanoma. Despite its excellent anti-cancer activity, the clinical use of vinblastine is often limited by its undesirable side effects, such as severe neuropathies and hepatotoxicity $[21,22]$.

In this study, we investigated the inhibitory effect of $\mathrm{C} 5$ extract (C5E) on the proliferation of B16F10 cells, its ability to induce apoptosis via both the extrinsic and intrinsic pathways, and its effect on PI3K/Akt/mTOR survival signaling pathways. Its influence on cell cycle progression and its combined cytotoxic effects with vinblastine were also investigated.

\section{EXPERIMENTAL}

\section{Plant materials and methods of extraction}

Herbal ingredients were obtained from the Oriental Medical Hospital, Dongguk University (Ilsan, Korea) and kindly authenticated by Dr. Seong Hyun Jeong (Department of Oriental Herbal Materials, Dongguk University). This formula consists of 10 Oriental medicinal herbs (Table 1).

Table 1: C5E formula consisting of 10 Oriental medicinal herbs

\begin{tabular}{llll}
\hline $\begin{array}{l}\text { Oriental } \\
\text { name }\end{array}$ & $\begin{array}{l}\text { Country } \\
\text { of origin }\end{array}$ & Grams & $\%$ \\
\hline Ginseng & Korea & 166 & 16.6 \\
Chaga & Russia & 166 & 16.6 \\
Pinellia Tuber & China & 111 & 11.1 \\
Sparganium Rhizome & China & 56 & 5.6 \\
Alpinia Rhizome & China & 56 & 5.6 \\
Cinnamon Bark & Vietnam & 56 & 5.6 \\
Astragalus Root & Korea & 56 & 5.6 \\
Psoraleae Semen & India & 111 & 11.1 \\
Evodiae Fruit & China & 111 & 11.1 \\
Meliae Fructus & China & 111 & 11.1 \\
$\quad$ Total & & 1000 & 100 \\
\hline
\end{tabular}

This was formulated for use in cancer patients. The 10 ingredients and their proportions $(\mathrm{w} / \mathrm{w})$ were as follows: Ginseng, Korea, $16.6 \%$; Chaga, China, $16.6 \%$; Pinellia Tuber, China, $11.1 \%$; Sparganium Rhizome, China, $5.6 \%$; Alpinia Rhizome, China, $5.2 \%$; Cinnamon Bark, Vietnam, $5.2 \%$; Astragalus Root, Korea, $5.6 \%$; Psoraleae Semen, India $11.1 \%$; Evodia Fruit, China, $11.1 \%$; Meliae Fructus, China, $11.1 \%$

\section{Extraction of C5E and constituent herbs}

The ethanol extract was prepared as follows: The dried and pulverized medicinal herbs were mixed together and a 1-kg batch was soaked with $40 \%$ ethanol (3 liters). The ethanol extract was concentrated using a rotary evaporator, lyophilized, and reconstituted in dimethysulfoxide (DMSO) for in vitro studies.

\section{Cell culture}

Human melanoma A375, murine melanoma B16F10, and human small lung $\mathrm{NCl}-\mathrm{H} 1299$ p53 $(-/-)$ cancer cells, and the human normal keratinocyte cell line HaCaT, were purchased from the American Type Culture Collection (ATCC, Manassas, VA). B16F10, HaCaT, and $\mathrm{NCl}-\mathrm{H} 1299$ p53 (-/-) cells were grown in Dulbecco's modified Eagle medium (DMEM) and in RPMI 1640 medium supplemented with $10 \%$ 
heated inactivated fetal bovine serum, 100 units $/ \mathrm{mL}$ of penicillin, and $100 \mu \mathrm{g} / \mathrm{mL}$ of streptomycin in a humidified atmosphere containing $5 \% \mathrm{CO}_{2}$ and $95 \%$ air at $37^{\circ} \mathrm{C}$.

\section{Cell viability}

The anti-proliferative effect of $\mathrm{C} 5 \mathrm{E}$ on $\mathrm{A} 375$, B16F10, and $\mathrm{NCl}-\mathrm{H} 1299$ p53 (-/-) cells and $\mathrm{HaCaT}$ cells was determined using the Cell Counting Kit (CCK)-8 (Dojindo Laboratories, Kumamoto, Japan), according to the manufacturer's instructions. All cells $(1 \times$ $10^{4} /$ well) were incubated in 96-well plates. Subsequently, the cells were treated with various concentrations of $\operatorname{C5E}(50,100,200$, and 400 $\mu \mathrm{g} / \mathrm{mL}$ ) for 24 and $48 \mathrm{~h}$. To examine the combined effects with vinblastine sulfate, B16F10 cells were treated with various concentrations of C5E $(50,100,200$ and 400 $\mu \mathrm{g} / \mathrm{mL})$ and vinblastine $(0,0.125,0.25,0.5,55$, $110 \mathrm{nM})$ for 24 and $48 \mathrm{~h}$. CCK-8 (10 $\mu \mathrm{l})$ was added to each well, and the cells were incubated for $3 \mathrm{~h}$. The absorbance was measured at 450 $\mathrm{nm}$ using a microplate reader and the completed medium was used as the blank. Cytotoxicity in the C5E-treated culture was expressed as follows:

Death $(\%)=(\mathrm{C} 5 / \mathrm{Cm}) 100$

Where $\mathrm{C} 5$ and $\mathrm{Cm}$ are the absorbance of $\mathrm{C} 5 \mathrm{E}-$ and $\mathrm{Cm}$-treated cells, respectively.

\section{Morphological examination immunofluorescence microscopy}

by

B16F10 cells were seeded on sterilized coverslips in 24 -well plates $\left(0.5 \times 10^{4}\right.$ cells/well), incubated overnight, and then treated with various concentrations of C5E. After $24 \mathrm{~h}$, the cells on the coverslip were washed twice with serum-free medium, fixed, and permeabilized with cold acetone on ice for $10 \mathrm{~min}$. The coverslips were washed with phosphate-buffered saline (PBS) 3 times and blocked with $0.1 \%$ bovine serum albumin (BSA) in PBS at room temperature for $30 \mathrm{~min}$.

The primary antibody (against cleaved caspase 7; Cat. Sc-8008; Santa Cruz Biotechnology, Santa Cruz, CA) was diluted (1:100) in $0.1 \%$ BSA in PBS and added to the coverslip at $4{ }^{\circ} \mathrm{C}$ overnight. After washing with PBS 3 times, the coverslip was incubated with the secondary antibody (fluorescein isothiocyanate [FITC]conjugated goat anti-mouse IgG) diluted (1:400) in $0.1 \% \mathrm{BSA}$ in PBS for $1 \mathrm{~h}$. The slide was then washed 3 times with PBS, exposed to 4', 6diamidino-2-phenylindole (DAPI; 1:1,000) for 10 s, and washed with PBS twice. The stained cells were visualized using an uplight fluorescence microscope (Olympus, Tokyo, Japan).

\section{Analysis of cell cycle distribution and apoptosis}

To examine cell cycle progression, B16F10 cells $\left(2.5 \times 10^{5}\right.$ cells per 6 -well plate) were treated with various concentrations of $\operatorname{C5E}(0,0.2$, and 0.4 $\mathrm{mg} / \mathrm{ml}$ ) and vinblastine (55 $\mathrm{nM})$ for $24 \mathrm{~h}$. To examine the phase distribution of the DNA content of the cells, propidium iodide (PI; Sigma, St. Louis, MO) staining was performed. After treatment, the cells were harvested and fixed in $70 \%$ ethanol. The fixed cells were washed with PBS, incubated with RNase A (5 mg/ml) for 30 min, stained with PI $(1 \mathrm{mg} / \mathrm{ml})$ for $5 \mathrm{~min}$ at room temperature in the dark. To determine the apoptosis induced by C5E in B1610 melanoma cells, annexin V staining (BD Bioscience, San Jose, CA) was performed according to the manufacturer's instructions. B16F10 cells $(2.5 \times$ $10^{5}$ cells per 6 -well plates) were treated with various concentrations of $\operatorname{C5E}(0,200$, and 400 $\mu \mathrm{g} / \mathrm{mL}$ ) and co-treated with vinblastine $(55 \mathrm{nM})$ for $24 \mathrm{~h}$, and subsequently labeled with $10 \mu \mathrm{g} / \mathrm{mL}$ $\mathrm{PI}$ and annexin V-FITC. Apoptosis and cell cycle distribution of C5E-treated B16F10 melanoma cells were assessed using a BD FACSCalibur flow cytometer (BD Biosciences) using CellQuest Software. The percentages of cells in different phases of the cell cycle were analyzed using the WinMDI Version 2.9 program (Copyright. 1993 2000; Joseph Trotter).

\section{Western blot analysis}

B16F10 cells $\left(2.5 \times 10^{5} / \mathrm{mL}\right)$ were plated in each 60-mm culture dish prior to drug treatment. After $24 \mathrm{~h}$ of cell attachment, cells were treated with either growth medium alone, as control, or with varying concentrations of $\operatorname{C5E}(0,200$, and 400 $\mu \mathrm{g} / \mathrm{mL}$ ) and co-treated with vinblastine $(55 \mathrm{nM})$ for $24 \mathrm{~h}$. At the end of the treatment, cells were lysed and protein concentrations were determined by the Bio-Rad protein assay kit (Pierce, Rockford, IL) with albumin as the standard. All samples (30-40 $\mu \mathrm{g}$ of proteins) were subjected to $12 \%$ sodium dodecyl sulfate polyacrylamide gel electrophoresis (SDS-PAGE). The proteins in the gels were then transferred to nitrocellulose membranes. After blocking the membranes with $5 \%$ non-fat milk, the membranes were then incubated with antibodies against p-Akt, Akt, cyclin B1, cyclin D1, cyclin D3, cyclin E, p-p53, p53, PARP, cleaved caspase-3, p27, p21, Bax, Bcl-2, and glyceraldehyde phosphate dehydrogenase (GAPDH) at $4{ }^{\circ} \mathrm{C}$ overnight. The membranes 
were washed 3 times in PBST (10 $\mathrm{mM} \mathrm{NaH}_{2} \mathrm{PO}_{4}$, $130 \mathrm{mM} \mathrm{NaCl}, 0.05 \%$ Tween 20), and then probed with secondary antibodies (horseradish peroxidase-conjugated anti-rabbit and antimouse antibodies; 1:2000 in blocking solution) for $1 \mathrm{~h}$. After washing with PBST 3 times, enzyme activity on the blot was visualized through chemiluminescence by adding ECL Western Blotting Reagents (Pierce).

\section{Statistical analysis}

The results were pooled from 3 independent experiments. Data from the cell viability assay and flow cytometric analyses are expressed as mean \pm standard error of the mean (SEM) and analysis of variance (ANOVA) followed by Tukey's test and Dunnet's test performed on GraphPad Prism 5 (San Diego, CA) to determine significant differences $(p \leq 0.05)$ between experimental groups.

\section{RESULTS}

\section{The chemical content of C5E}

C5E contained Ginseng (Korea, $16.6 \%$ ), Chaga (China, $16.6 \%$ ), Pinellia tuber (China, $11.1 \%$ ), Sparganium rhizome (China, $5.6 \%$ ), Alpinia rhizome (China, $5.2 \%$ ), Cinnamon bark (Vietnam, $5.2 \%$ ), Astragalus root (Korea, $5.6 \%$ ), Psoraleae semen (India $11.1 \%$ ), Evodia Fruit (China, $11.1 \%$ ), and Meliae fructus (China, 11.1 $\%)$. We identified the potential medicinal components of the $\mathrm{C} 5 \mathrm{E}$ extract using gas chromatography mass spectrometry (GC-MS; Figure 1).

Compounds were identified by comparison with those in the Wiley 6th edition MS spectra library (in the library search program, hits that were $>90$ $\%$ probable were viewed as likely hits). Table 2 lists the chemical components of the extract. The analysis yielded 1 compound, coumarin, which is known to have anti-cancer properties (Figure 1, Table 2).

\section{The anti-tumor effects of C5E with vinblastine}

We first investigated cytotoxic responses in HaCaT cells, NCl-H1299 p53 (-/-) cells, B16F10 cells, and A375 cells exposed to various concentrations of C5E (50, 100, 200, and 400 $\mu \mathrm{g} / \mathrm{mL}$ ) for $24 \mathrm{~h}$ and $48 \mathrm{~h}$. HaCaT normal keratinocytes were not affected by C5E (Figure 2A). C5E was cytotoxic to B16F10 cells with an $\mathrm{IC}_{50}$ value of $0.3 \mathrm{mg} / \mathrm{ml}$ after $24-\mathrm{h}$ treatment (Figure 2C). Treatment of B16F10 cells for $48 \mathrm{~h}$ induced more significant cell death compared to 24-h-treatment at $\mathrm{C} 5 \mathrm{E}$ concentrations of 0.1 to $0.8 \mathrm{mg} / \mathrm{ml}$ (Figure 2C); the $\mathrm{NCl}-\mathrm{H} 1299$ p53 knockout cells were also affected in a dosedependent manner, but to a lesser extent than B16F10 cells (Figure 2B). This means that C5E may induce cell death by not only a p53dependent pathway but also a p53-independent pathway in melanoma cells. The other melanoma cells, A375, were only slightly inhibited by C5E, compared to B16F10 cells (Figure 2D).

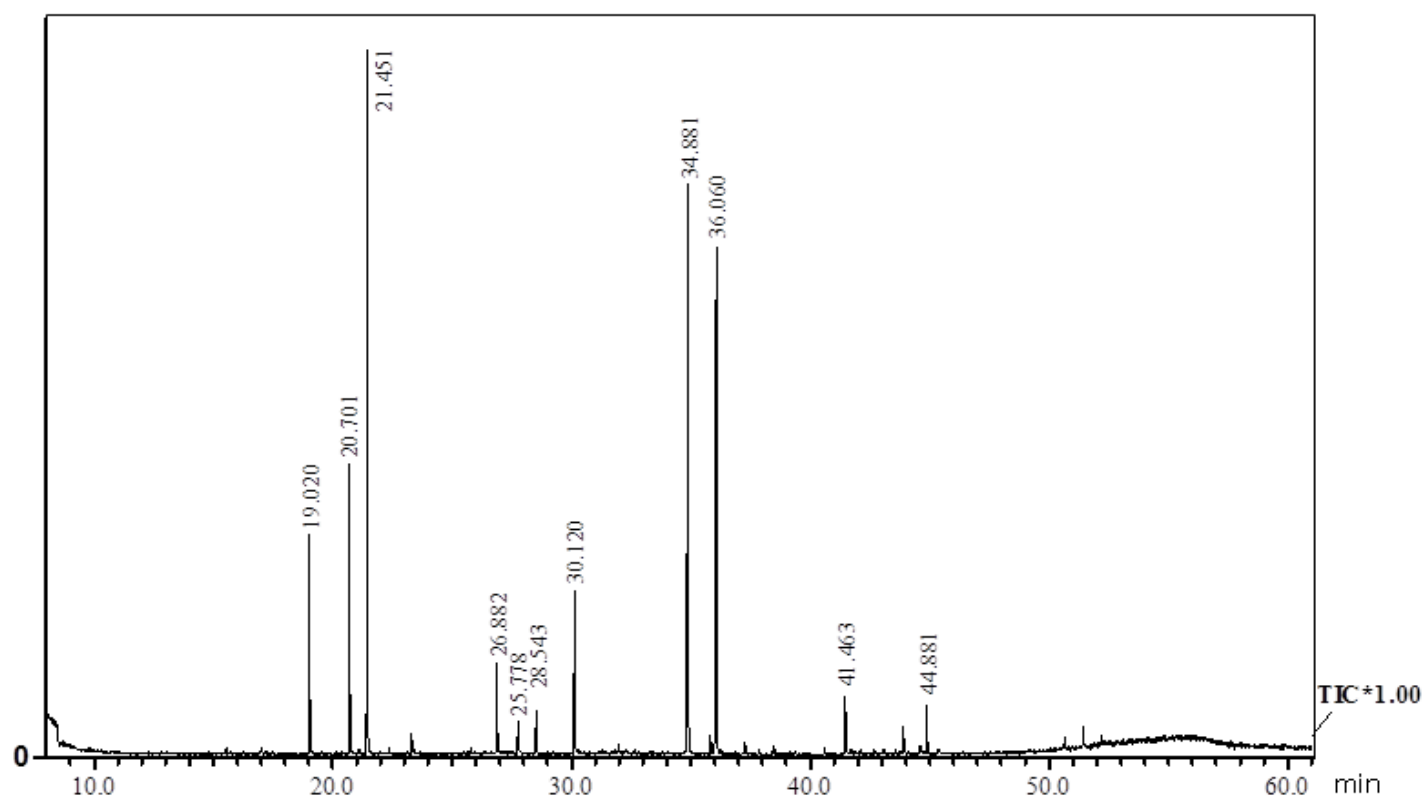

Figure 1: Composition of C5E was analyzed by GC-MS. Among the volatile compounds in C5E, 1-phenyl-3butanone, angelicin and ficusin are major components. Coumarin, which has anti-cancer properties, was also identified 
A.

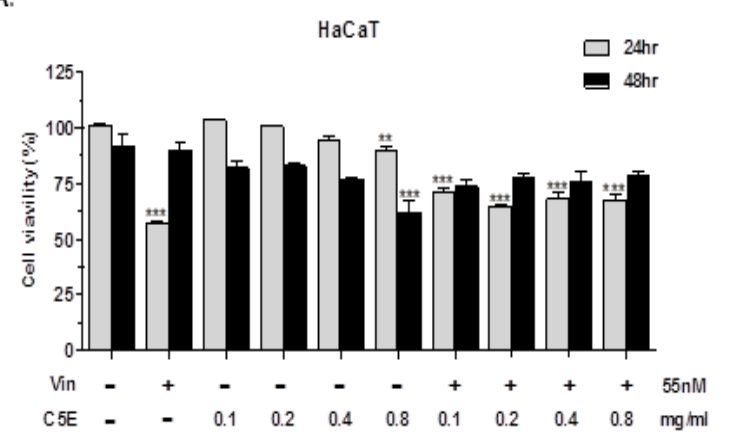

C.

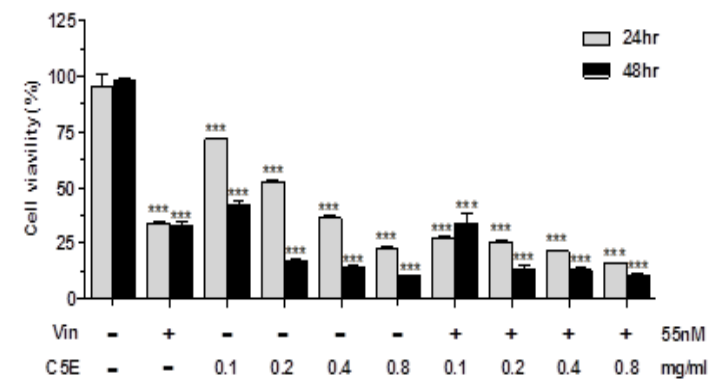

B
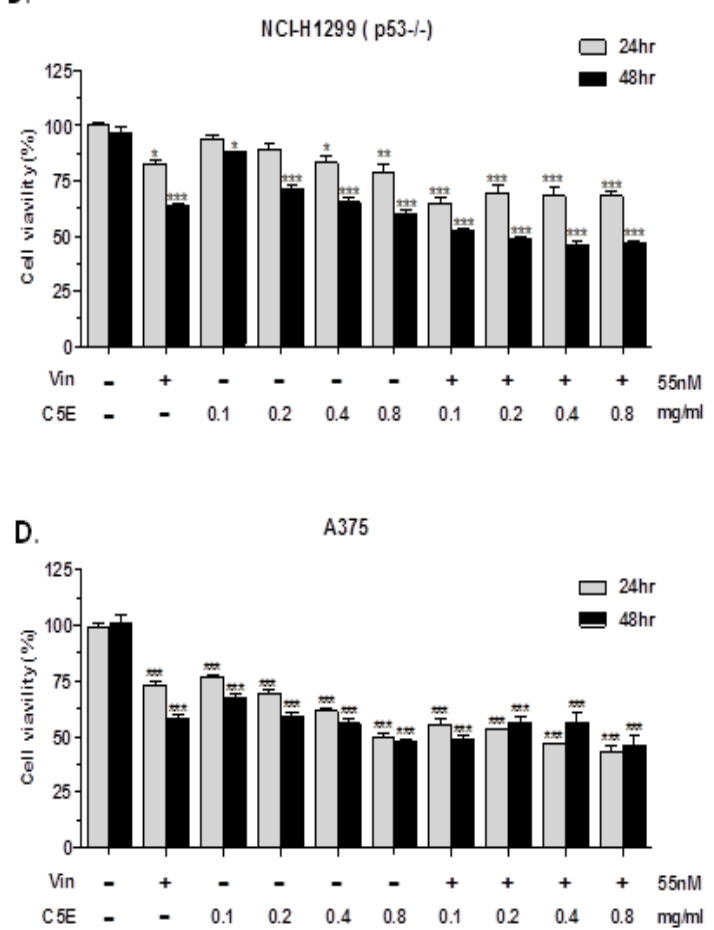

Figure 2: Dose- and time-dependent effects of C5E on the proliferation of several cell lines. (a) Human keratinocyte cells, HaCaT; (b) NCl-H1299, p53 knockout cells; (c) mouse melanoma cells, B16F10; (d) Human melanoma cells and A375 cells were treated for $24 \mathrm{~h}$ with different concentrations of C5E in the presence or absence of $55 \mathrm{nM}$ vinblastine. Cell viability was determined by the CCK-8 assay. The data were normalized to the control cells. Data are expressed as the mean $\pm \operatorname{SD}(n=5)$. ${ }^{*} p<0.05,{ }^{* *} p<0.001,{ }^{* * *} p<0.0001$, compared to untreated control

Table 2: Volatile compounds identified in C5E

\begin{tabular}{lcl}
\hline Compounds & $\begin{array}{l}\text { Retention } \\
\text { time (min) }\end{array}$ & $\begin{array}{l}\text { Relative } \\
(\%)\end{array}$ \\
\hline 3-Phenylpropanal & 19.020 & 7.41 \\
3,4-Dimethyl-benzaldehyde & 20.701 & 9.55 \\
1-Phenyl-3-butanone & 21.451 & 23.53 \\
Coumarin & 26.882 & 2.65 \\
Methyldymron & 27.755 & 1.05 \\
2,4-Di-tert-butylphenol & 28.543 & 0.78 \\
Coniferyl alcohol & 30.120 & 4.93 \\
Angelicin & 34.881 & 24.54 \\
Ficusin & 36.060 & 22.05 \\
Unknown & 41.463 & 1.89 \\
Priscoline & 44.881 & 1.61 \\
\hline
\end{tabular}

Vinblastine was used at the optimal dose (55 nM) for its anti-cancer effect, as a positive control for comparison with the effects of C5E. The results, shown in Fig. 2, indicated that C5E inhibited the proliferation of A375 cells and B16F10 cells at $100 \mu \mathrm{g} / \mathrm{ml}$, reaching a maximum cell death percentage of $\sim 75 \%$ and $\sim 48 \%$ in the presence of $800 \mu \mathrm{g} / \mathrm{ml}$ (Figure 2C, 2D), but this was not seen in normal human keratinocyte HaCaT cells and this effect occurred in a concentrationdependent manner. Figure $2 \mathrm{C}$ shows that $\mathrm{C5E}$ enhances the antitumor efficacy of vinblastine in the B16F10 melanoma cell line. Therefore, C5E showed strong anti-cancer activity with low toxicity to normal cells. To further examine the potential anti-cancer effects of C5E, its combined inhibitory effect with vinblastine on the proliferation of B16F10 cells were investigated. The cells were incubated with various doses of C5E for $24 \mathrm{~h}$ and $48 \mathrm{~h}$ with vinblastine (55 nM). Vinblastine showed combined inhibitory effects with various doses of $\mathrm{C} 5 \mathrm{E}(0.2,0.4$, and 0.8 $\mathrm{mg} / \mathrm{mL}$ ) on B16F10 cells, but only slight combined inhibitory effects were observed on HaCaT, NCl-H1299 (p53-/-), and A375 cells (Figure 2). Combined inhibitory effects on cell proliferation were observed clearly with $0.2,0.4$, and $0.8 \mathrm{mg} / \mathrm{ml}$ C5E plus $55 \mathrm{nM}$ vinblastine, respectively, compared to $\mathrm{C} 5 \mathrm{E}$ alone (Figure $2 \mathrm{C})$. On the other hand, the $\mathrm{NCl}-\mathrm{H} 1299$ p53 knockout cells were affected in a dosedependent manner, but to a lesser extent than B16F10 cells (Figure 2B).

\section{Apoptosis of B16F10 cells treated with C5E}

To investigate the apoptosis-induced effects of C5E, B16F10 cells exposed to C5E were 


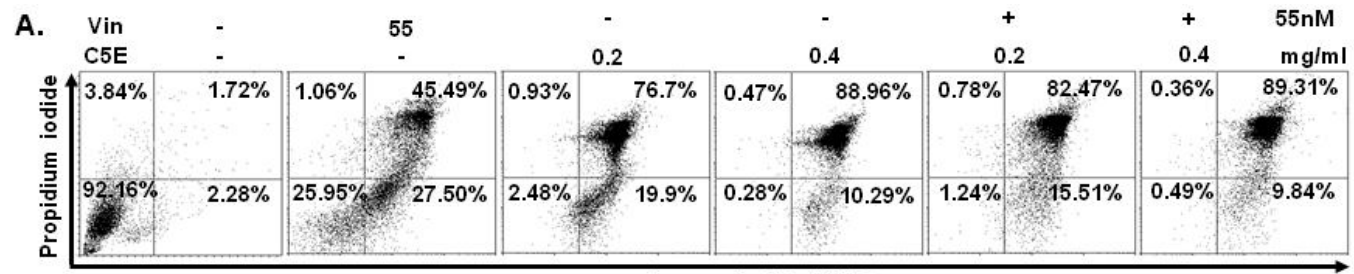

Annexin V- FITC

B.

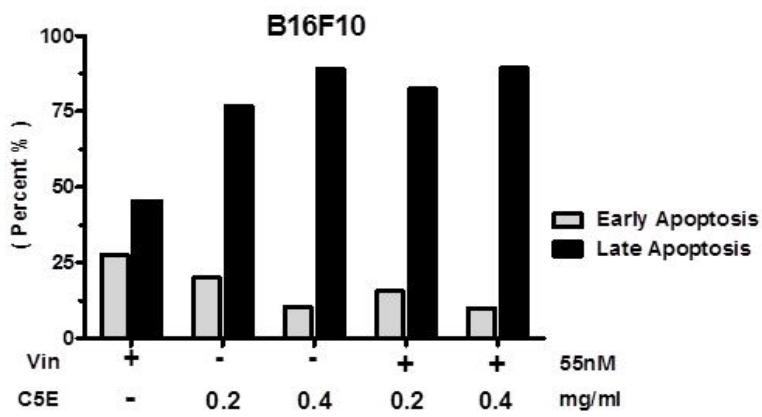

c.

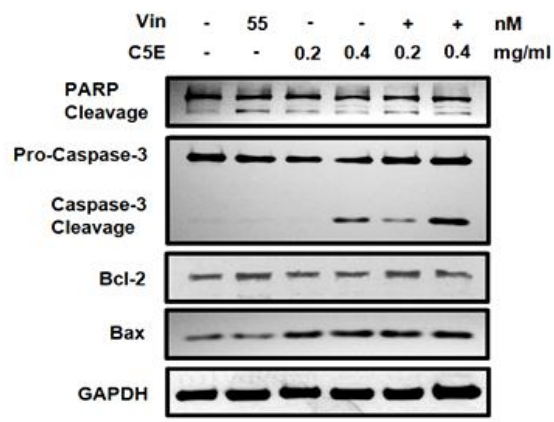

Figure 3: Effect of C5E on apoptosis in B16F10 cells. (A, B) B16F10 cells were treated with various concentrations of C5E $(0.2$ and $0.4 \mathrm{mg} / \mathrm{ml})$ in the presence or absence of $55 \mathrm{nM}$ vinblastine for $24 \mathrm{~h}$. Cellular apoptosis was measured by flow cytometry using double-staining with FITC-conjugated annexin $\mathrm{V}$ and $\mathrm{PI}$. Annexin-positive/PI-negative cells have undergone early apoptosis. Annexin-positive/PI-positive cells are in late apoptosis. (C) Immunoblot analysis of cleaved PARP, pro-caspase-3, cleaved caspase-3, Bcl-2, and Bax levels in cell lysates from C5E- and vinblastine-treated B16F10 cells

analyzed using annexinV-FITC \& PI staining on a flow cytometer (Becton-Dickinson, Franklin Lakes, NJ). Annexin- and Pl-negative cells are live cells (Q3), and PI single-staining (annexinnegative) represents necrotic cells (Q2). Annexin-positive/PI-negative cells (Q4) are those that have undergone early apoptosis, whereas annexin- and Pl-positive cells (Q1) are late apoptotic cells. The control cells were in Q3, which indicates that the cells were alive and in good condition. In contrast, C5E-treated cells appeared in Q1 and Q4, which represent cells undergoing apoptosis. Our results demonstrate that C5E induces apoptosis in a dose-dependent manner. The number of B16F10 cells in the subG1 phase increased significantly after treatment with 0.2 and $0.4 \mathrm{mg} / \mathrm{mL}$ C5E (Figure $3 \mathrm{~A}, \mathrm{~B}$ ).

Vinblastine slightly increased the apoptotic effect of $\mathrm{C} 5 \mathrm{E}$ at 0.2 and $0.4 \mathrm{mg} / \mathrm{ml}$. To confirm these results, the effects exerted by C5E on the activity of apoptosis-inducing proteins in B16F10 cells were studied. C5E increased the activation of caspase-3 cleavage and Bax. To further confirm these results, we performed immunofluorescence to track caspase-7 (Figure 4).

These results suggest that C5E induced apoptosis by enhancing the caspase signal pathway.

\section{C5E inhibits cell cycle progression and modulates cell cycle-related factors}

We investigated the effects of C5E on cell cycle regulation. Cell cycle progression was measured by $\mathrm{PI}$ staining with quantitation of DNA content using flow cytometry. As shown in Figures $5 \mathrm{~A}$ and $5 \mathrm{~B}$, the non-treated cells were mainly present in the G0/G1 phase, whereas the C5Etreated cells cycled into the sub-G1 phase in a dose-dependent manner.

To confirm these results, we performed immunoblots to analyze cell cycle regulatory factors. P53 is involved in the G1/S and G2/M phases and is active in the phosphorylated form (20). We investigated DNA degradation in a dose-dependent manner (Figure 5C). Cell cycle regulatory factors such as p53 and p-p53 were upregulated by $\mathrm{C} 5 \mathrm{E}$, thereby terminating the cell cycle at the $\mathrm{G} 1$ phase and preventing cell division. Cyclin B1 was downregulated by C5E treatment in a dose-dependent manner (Figure 5C). These results indicate that treatment with C5E is capable of inducing apoptosis and delaying the cell cycle at the G0/G1 phase in B16F10 melanoma cells. 


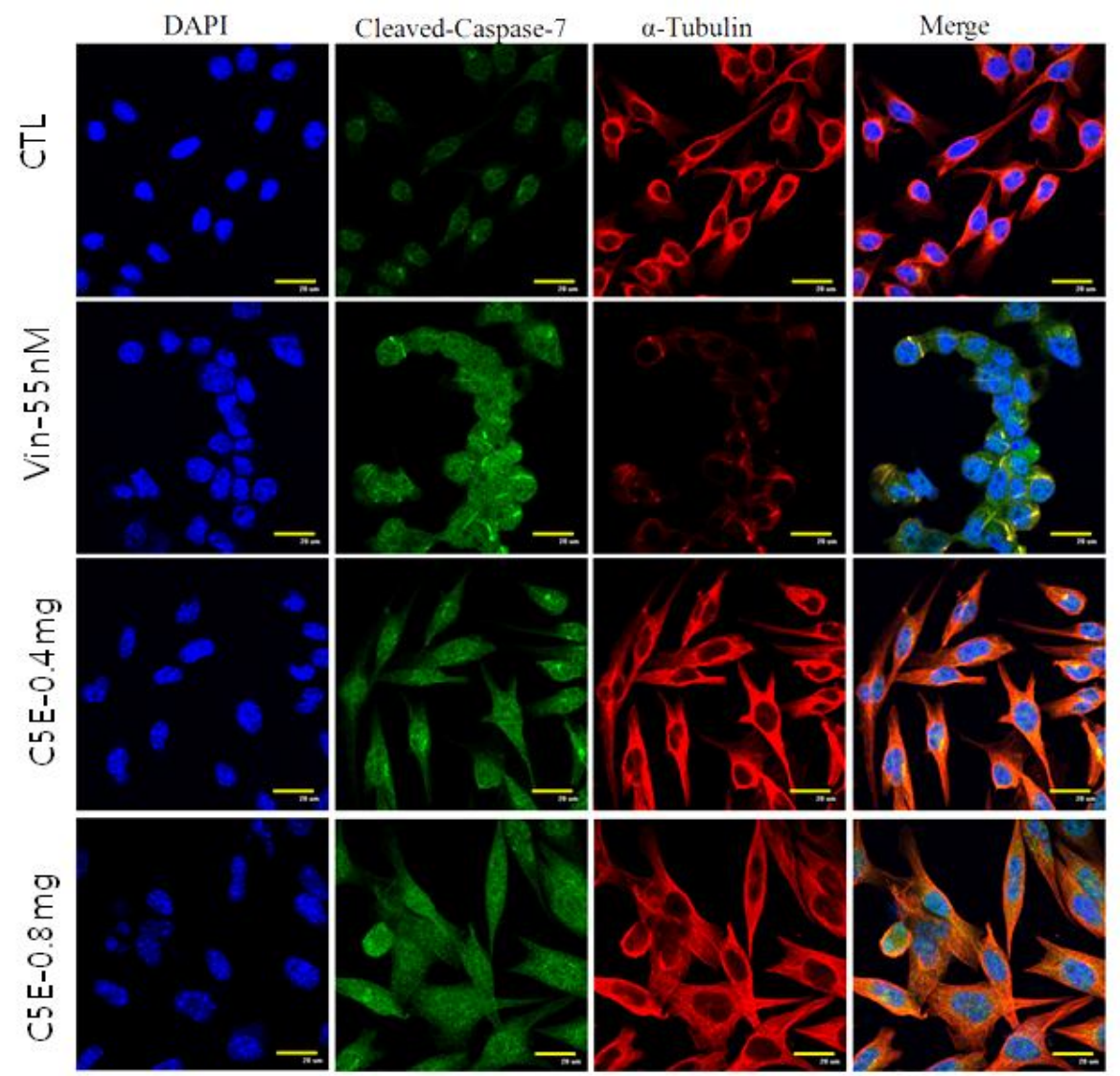

Figure 4: Immunofluorescence was performed to measure the amount of cleaved caspase-7 in B16F10 melanoma cells. B16F10 cells were treated with various concentrations of C5E (0.2 and $0.4 \mathrm{mg} / \mathrm{ml})$ and vinblastine $(55 \mathrm{nM})$ for $24 \mathrm{~h}$. Fixed and stained cleaved caspase-7 (green fluorescence), a-tubulin (red fluorescence), and nuclei (blue fluorescence) were detected using immunofluorescence confocal microscopy

A.

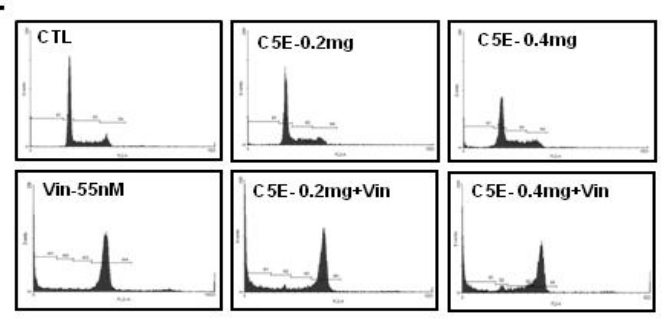

B.

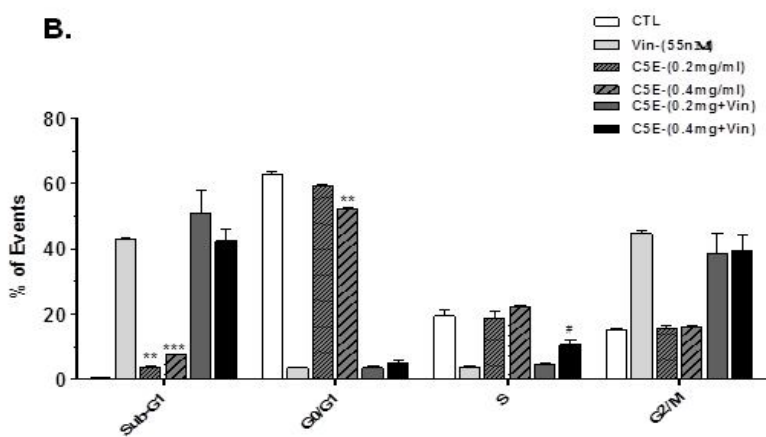

c.

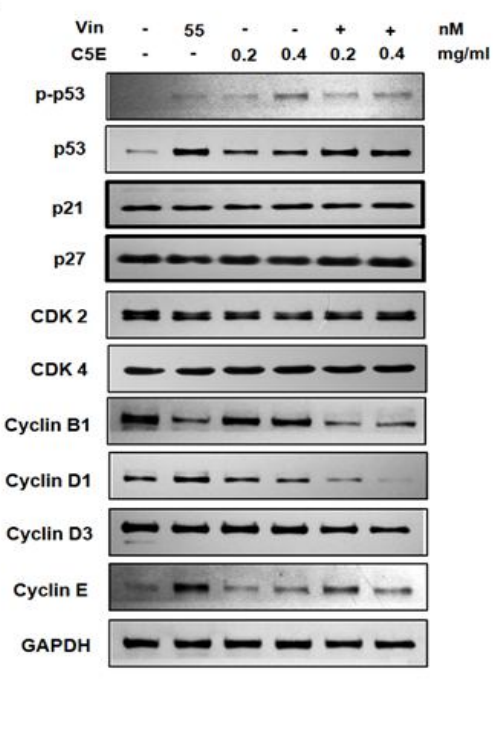

Figure 5: Effects of C5E on cell cycle progression in B16F10 cells. (A) Cell cycle profiles of B16F10 cells treated with various concentrations of $\operatorname{C5E}(0,0.2,0.4 \mathrm{mg} / \mathrm{ml})$ in the presence or absence of $55 \mathrm{nM}$ vinblastine for $24 \mathrm{~h}$. (B) The proportions of the population in the different cell cycle phases, quantified from the profiles, are represented in the bar graphs along with the SEM of 3 independent experiments. ${ }^{*} p<0.05$, ${ }^{* *} p<0.001$, ${ }^{* * *} p<$ 0.0001 , compared to untreated control. (C) Immunoblots of cell cycle regulatory factors. GAPDH was used as an internal control 
C5E downregulates expression of MAPKs, PI3K/Akt, and mTOR signaling pathways in B16F10 cells

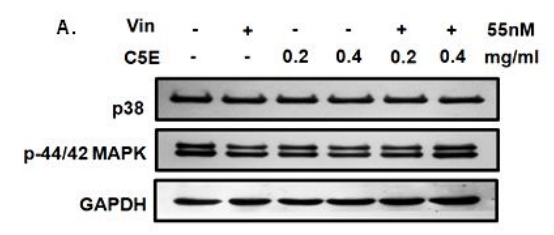

B. Vin - + - + + $+55 \mathrm{nM}$

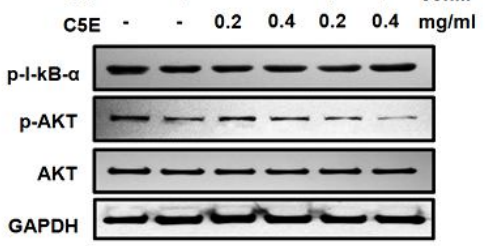

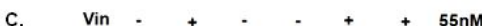
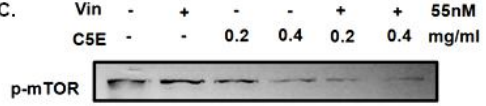

mTOR $\longrightarrow-\square$

GAPDH $--\infty-\cdots$

Figure 6: Effect of C5E on the expression of survival signaling factors in B16F10 cells. B16F10 cells were treated with various concentrations of $\operatorname{C5E}(0,0.2$, and $0.4 \mathrm{mg} / \mathrm{ml}$ ) in the presence or absence of $55 \mathrm{nM}$ vinblastine for $24 \mathrm{~h}$. (A) p38 and p-44/42 MAPK were detected by Immunoblot analysis. (B) The expression of $p$-lkB- $\alpha$ and $p-A K T$ were detected by immunoblot analysis (C). p-mTOR was detected by immunoblot analysis

To further study the effects of C5E on cell proliferation, protein expression levels of members of the MAPKs, PI3K/Akt, and mTOR signaling pathways were investigated. pMAPK, p-lkB-a, p-Akt, p-mTOR, and mTOR were downregulated by $\mathrm{C} 5 \mathrm{E}$ as expected (Figure $6 \mathrm{~A}$, $B, C)$. However, $p-38$ and Akt were not significantly altered (Figures $6 \mathrm{~A}$ and $6 \mathrm{~B}$ ).

\section{DISCUSSION}

C5E is a herbal composition designed to cure cancer in a herbal clinic. This herb extract has long been used as an anti-cancer agent at the Oriental Hospital. C5E is composed of ethanol extracts from a mixture of Ginseng, Chaga, Pinellia Tuber, Sparganium Rhizome, Alpinia Rhizome, Cinnamon Bark, Astragalus Root, Psoraleae Semen, Evodia Fruit, and Meliae Fructus. There have been several reports regarding these materials, but this study is the first to analyze the effect of these extracts on B16F10 melanoma cells [23-25]. In this study, the following effects of C5E ethanol extracts were examined: inhibition of the proliferation of B16F10 and keratinocyte cells, apoptotic signaling pathway in B16F10 cells, induction of cell cycle arrest in B16F10 cells, and inhibition of the proliferation of B16F10 cells when combined with vinblastine. C5E dose-dependently inhibited the proliferation of the melanoma cell lines in this study. C5E at $800 \mu \mathrm{g} / \mathrm{mL}$, the maximal inhibitory dose in terms of cell proliferation, effectively suppressed the proliferation of B16F10 cells (77 $\%$ inhibition of proliferation) and keratinocytes (36\% inhibition of proliferation). To further investigate this finding, a time-course analysis was conducted with B16F10, A375, keratinocytes, and $\mathrm{NCl}-\mathrm{H} 1299$ cells incubated in the presence or absence of vinblastine $(55 \mathrm{nM})$ at 24 and $48 \mathrm{~h}$. The results showed that C5E had clearly continuous inhibitory effects in contrast to the control at $24 \mathrm{~h}$. The data showed that C5E has dose- and time-dependent inhibitory effects on the proliferation of both melanoma cell lines (Figures 2C and 2D).

Apoptosis is an important function for maintaining body systems because dysfunction of apoptotic signaling could cause serious conditions such as cancer and autoimmune disease [26]. Apoptosis is normally induced by the sequential activation of caspases, leading to cell death. Caspases are normally present in an inactive procaspase form but exist as a cleaved form when triggered. The extrinsic pathway of apoptosis involves the activation of caspase 8 , which can directly cause the activation of downstream caspases such as caspases-3, -6 , and -7 [27]. The intrinsic pathway controls mitochondria-dependent apoptosis, which leads to the activation of caspase 9 through apoptotic protease activating factor-1 (APAF-1) and cytochrome c release [28]. The cleavage of bid to tbid is induced by caspase 8 through the death receptor pathway of apoptosis and it mediates mitochondrial apoptosis $[29,30]$. In order to understand the cause of cytotoxic effects induced by C5E in B16F10 melanoma, we investigated apoptotic signaling using western blot analyses and immunohistochemistry.

Induction of apoptosis in B16F10 cells was determined by flow cytometry-based-annexin $\mathrm{V}$ staining. C5E from 200 and $400 \mu \mathrm{g} / \mathrm{ml}$ enhanced the percentage of apoptotic melanoma cells (Figures $3 \mathrm{~A}$ and $3 \mathrm{~B}$ ). The present data show that C5E can induce the apoptosis of B16F10 cells through the activation of caspases-3, -7, Bax, and PARP (Figure $3 \mathrm{C}$, Figure 4), suggesting that C5E induces apoptosis through both of the major mechanisms, the extrinsic and the intrinsic pathway [6]. The inhibitory effects of C5E on cell proliferation were further studied by analyzing the 
cell cycle. The cell cycle consists of 4 distinct phases, the G1, S, G2, and M phases. Each phase has a checkpoint that is regulated by many proteins. If a DNA mutation is detected, p53 blocks cell cycle progression and repairs the damaged DNA or induces apoptosis [31]. C5E $(0.4 \mathrm{mg} / \mathrm{ml})$ caused cell cycle arrest in the subG1 phase in B16F10 melanoma cells (Figure 5) suggesting that $\mathrm{C} 5 \mathrm{E}$ participated partly in the anti-proliferation of B16F10 cells via sub-G1 phase arrest in addition to the apoptotic pathway. Cell cycle-related proteins, such as p53, p-p53, and CDK4, were activated.

However, cyclins, which drive the cell cycle forward, were slightly down regulated (Figure 5C). Although C5E showed weak cell cycle arresting effects in contrast to vinblastine, its extract effectively caused apoptosis in the late stages (Figure 3). NF-kB is generally inhibited by IkB, which is regulated by IKK. IKK phosphorylates $\mathrm{IkB}$, which is subsequently degraded by the proteasome. Then, free NF-kB translocates to the nucleus and turns on cell survival-related genes [32]. Several reports revealed that inhibition of the NF-kB and $\mathrm{PI} 3 \mathrm{~K} / \mathrm{Akt}$ signaling pathways can induce apoptosis in cancer cells [33,34]. The present results show that $p$-Akt/Akt as well as $p$-lkB levels were decreased by $\mathrm{C} 5 \mathrm{E}$ and the maximal combined effect against p-Akt was caused with $0.4 \mathrm{mg} / \mathrm{mL}$ C5E plus vinblastine (Figure $6 \mathrm{~B}$ ).

It has been shown that the protein mTOR is phosphorylated in several lung cancer cell lines $[35,36]$. Importantly, mTOR activation was more frequent in tumors with gene alterations such as EGFR mutations or PI3K/Akt over-expression [37]. Phosphorylation of mTOR was decreased by $\mathrm{C} 5 \mathrm{E}$ and a combined effect was caused by $0.4 \mathrm{mg} / \mathrm{ml} \mathrm{C5E}$ plus vinblastine (Figure 6C). These results suggest that C5E inhibits cell survival signals and interrupts cell proliferation by interfering with the Akt and mTOR signaling pathways.

\section{CONCLUSION}

We have demonstrated that C5E can inhibit effectively the proliferation of B16F10 and A375 melanoma cells via the induction of apoptotic signaling through both intrinsic and extrinsic pathways while inactivating the phosphorylation of Akt and IkB. This extract can also cause cell cycle arrest at the sub-G1 phase. The extract also showed a combined effect with vinblastine on the inhibition of cell proliferation, but it was not cytotoxic to normal cells, indicating that it may act effectively as an anti-cancer agent with minimal side effects. However, further studies are required to investigate the uses of this extract for pre-clinical development.

Our results indicate that C5E has multiple effects in the induction of apoptosis and the inhibition of tumor survival and growth, and may be a useful complementary agent during vinblastine chemotherapy by enhancing its antitumor efficacy.

\section{ACKNOWLEDGEMENT}

This study was supported by a grant (B110053) from the Korean Health Technology R\&D Project, Ministry of Health \& Welfare, Republic of Korea.

\section{REFERENCES}

1. Chia JS, Du JL, Hsu WB, Sun A, Chiang CP, Wang WB. Inhibition of metastasis, angiogenesis, and tumor growth by Chinese herbal cocktail Tien-Hsien Liquid. BMC Cancer 2010; 10: 175176.

2. Mijatovic SA, Timotijevic GS, Miljkovic DM, Radovic JM, Maksimovic-Ivanic DD, Dekanski DP, Stosic-Grujicic SD. Multiple antimelanoma potential of dry olive leaf extract. Int J Cancer 2011; 128: 19551965.

3. Wagner $H$. Natural products chemistry and phytomedicine in the 21st century: new developments and challenges. Pure Appl Chem 2005; 77: 1-6.

4. Norbury, Hickson, Norbury CJ, Hickson ID. Cellular responses to DNA damage. Annual Review of Pharmacology and Toxicology 2001; 41: 367-401.

5. Nagata S. Apoptotic DNA fragmentation. Exp Cell Res 2000; 256: 12-18.

6. Igney, $\mathrm{FH}$, Krammer PH. Death and anti-death: tumour resistance to apoptosis. Nature Reviews Cancer 2002; 2: 277-288.

7. Kumar S. Caspase function in programmed cell death. Cell Death Differ 2007; 14: 32-43.

8. Wilson MR. Apoptotic signal transduction: emerging pathways. Biochem Cell Biol 1998; 76: 573-582.

9. Sun XM, MacFarlane $M$, Zhuang J, Wolf BB, Green DR, Cohen G.M. Distinct caspase cascades are initiated in receptor-mediated and chemical-induced apoptosis. J Biolog Chem 1999: 274: 5053-5060.

10. Cory S, Adams JM. The Bc/2 family: regulators of the cellular life-or-death switch. Nat Rev Cancer 2002; 2: 647-656.

11. Debatin K. Activation of apoptosis pathways by anticancer treatment. Toxicol Letters 2000; 112-113: 41-48.

12. Shaw RJ, Cantley LC. Ras, PI(3)K and mTOR signalling controls tumour cell growth Nature 2006; 441: 424430.

13. Morgensztern D, McLeod HL. PI3KJAkt/mTOR pathway as a target for cancer therapy. Anticancer Drugs 2005; 16: 797-803.

Trop J Pharm Res, June 2015; 14(6): 975 
14. Faissner A, Heck N, Dobbertin A, garwood J. DSD-1Proteoglycan Phosphacan and receptor protein tyrosine phosphatasebeta isoforms during development and regeneration of neural tissues. Adv Exp Med Biol 2006; 557: 25-53.

15. Alvarez M, Roman E, Santos ES, Raez LE. New targets for non-small-cell lung cancer therapy. Expert Rev Anticancer Ther 2007; 7: 1423-1437.

16. Scott PH, Brunn GJ, Kohn AD, Roth RA, Lawrence Jr JC. Evidence of insulin-stimulated phosphorylation and activation of the mammalian target of rapamycin mediated by a protein kinase $B$ signaling pathway. Proc Natl Acad Sci USA 1998; 95(13): 7772-7777.

17. Nave $B T$, Ouwens $M$, Withers $D J$, Alessi DR, Shepherd $P R$. Mammalian target of rapamycin is a direct target for protein kinase $B$ : identification of a convergence point for opposing effects of insulin and amino-acid deficiency on protein translation. Biochem $J$ 1999; 344(2): 427-431.

18. Ballif BA, Roux PP, Gerber SA, MacKeigan JP, Blenis J, Gygi SP. Quantitative phosphorylation profiling of the ERK/p90 ribosomal S6 kinase-signaling cassette and its targets, the tuberous sclerosis tumor suppressors. Proc Natl Acad Sci USA 2005; 102(3): 667-672.

19. Ma L, Chen Z, Erdjument-Bromage H, Tempst $P$, Pandolfi PP. Phosphorylation and functional inactivation of TSC2 by Erk implications for tuberous sclerosis and cancer pathogenesis. Cell 2005; 121(2): 179-193.

20. Le Quesne P. Neuropathy due to drugs. In: Dyck PJ, Thomas PK, Griffin JW, Low PA, Poduslo JF, editors. Peripheral neuropathy. Philadelphia: WB Saunders, 1993: 1571-1581.

21. Spiller $M$, Marson $P$, Perilongo G, Farina $M$, Carli $M$, Bisogno $G$. A case of vinblastine overdose managed with plasma exchange. Pediatr Blood Cancer 2005; 45(3): 344-346.

22. Floyd J, Mirza I, Sachs B, Perry MC. Hepatotoxicity of Chemotherapy. Semin Oncol Rev 2006; 33(1): 50 67.

23. Ji Y, Rao Z, Cui J, Bao H, Chen C, Shu C, Gong JR. Ginsenosides extracted from nanoscale Chinese white ginseng enhances anticancer effect. J Nanosci Nanotechnol 2012; 12(8): 6163-6167.

24. Lemieszek MK, Langner E, Kaczor J, Kandefer-Szerszen M, Sanecka B, Mazurkiewicz W, Rzeski W. Anticancer effects of fraction isolated from fruiting bodies of Chaga medicinal mushroom, Inonotus obliquus (Pers.:Fr.) Pilat (Aphyllophoromycetideae): in vitro studies. Int J Med Mushrooms 2011; 13: 131143.
25. Watanabe S, Kitade $Y$, Masaki T, Nishioka M, Satoh K, Nishino $H$. Effects of lycopene and Sho-saiko-to on hepatocarcinogenesis in a rat model of spontaneous liver cancer. Nutr Cancer 2001; 39: 96-101

26. Mahoney JA, Rosen A. Apoptosis and autoimmunity. Curr Opin Immunol 2005; 17: 583-588.

27. Wilson M.R. Apoptotic signal transduction: emerging pathways. Biochem Cell Biol 1998; 76: 573-582.

28. Zou H, Li Y, Liu X, Wang X. An APAF-1-cytochrome $c$ multimeric complex is a functional apoptosome that activates procaspase-9. J Biol Chem 1999; 274: 11549-11556.

29. Luo X, Budihardjo I, Zou H, Slaughter C, Wang X. Bid, a $B c / 2$ interacting protein, mediates cytochrome $c$ release from mitochondria in response to activation of cell surface death receptors. Cell 1998; 94: 481-490.

30. Elmore S. Apoptosis: a review of programmed cell death. Toxicol Pathol 2007; 35: 495-516.

31. Moore A, Donahue CJ, Bauer KD, Mather JP. Simultaneous measurement of cell cycle and apoptotic cell death. Methods Cell Biol 1998; 57: 265-278.

32. Jacobs MD, Harrison SC. Structure of an IkappaBalpha/NF-kappaB complex. Cell 1998; 95: 749-758.

33. Gururajan $M$, Dasu $T$, Shahidain $S$, Jennings $C D$, Robertson DA, Rangnekar VM, Bondada S. Spleen tyrosine kinase (Syk), a novel target of curcumin, is required for B lymphoma growth. J Immunol 2007; 178(1): 111-121.

34. Hussain AR, Al-Rasheed M, Manogaran PS, Al-Hussein $K A$, Platanias LC, Al Kuraya K, Uddin S. Curcumin induces apoptosis via inhibition of PI30-kinase/AKT pathway in acute $T$ cell leukemias. Apoptosis 2006; 11: 245-254.

35. Balsara BR, Pei J, Mitsuuchi Y, Page R, Klein-Szanto A, Wang $H$, Unger $M$, Testa JR. Frequent activation of $A K T$ in non-small cell lung carcinomas and preneoplastic bronchial lesions. Carcinogenesis 2004; 25(11): 2053-2059.

36. Han S, Khuri FR, Roman J. Fibronectin stimulates nonsmall cell lung carcinoma cell growth through activation of Akt/mammalian target of rapamycin/S6 kinase and inactivation of LKB1/AMP-activated protein kinase signal pathways. Cancer Res 2006; 66(1): 315-323.

37. Conde E, Angulo B, Tang M, Morente M, Torres-Lanzas J, Lopez-Encuentra A, Lopez-Rios F, SanchezCespedes M. Molecular context of the EGFR mutations: evidence for the activation of $m T O R / S 6 K$ signaling. Clin Cancer Res 2006; 12(3): 710-717. 